Original article

\title{
Communities and tree-species preferences of birds in traditional agroforestry system in Meru Betiri National Park
}

\author{
Agung Sih Kurnianto ${ }^{*}$, Luhur Septiadi ${ }^{2}$, Puji Firmansyah ${ }^{3}$, Nilasari Dewi ${ }^{1}$ \\ ${ }^{1}$ Agrotechnology Study Program, Faculty of Agriculture, University of Jember, Kalimantan street no. 37, Jember, Indonesia \\ ${ }^{2}$ Department of Biology, Faculty of Science, Chulalongkorn University, Pathumwan 10330, Bangkok, Thailand \\ ${ }^{3}$ Meru Betiri National Park, Sriwijaya street no. 53, Jember, Indonesia
}

\begin{abstract}
Agroforestry is a critical component of providing primary habitat for birds. Meru Betiri National Park (MBNP) establishes a diverse array of ecologically and economically significant trees while allowing local residents to farm beneath them, resulting in the formation of a complex agroforestry system. The purpose of this study is to examine bird communities and their tree-species preferences across tree height levels in MBNP's traditional agroforestry system. For vegetation analysis, we used the circle method, and for bird data collection, we used the point count method in a single circle approach. For both vegetation and bird communities, the ecological indices (the important value index, Shannon-Wiener diversity index, Margalef species richness index, and evenness index) were calculated. Birds' ecological roles and activity preferences were analyzed using principal component analysis and presented in stratified tree height levels. The results indicated that insectivores' birds are the primary insect predators in the traditional MBNP agroforestry system (11 out of 16 bird families). Artocarpus heterophyllus was the most frequently visited tree species out of seven, which may have significant ecological value (for bird diversity) and economic benefits (for avitourism). Finally, one can deduce that the majority of bird activity occurs between 4 and 20 meters above the ground.
\end{abstract}

Keywords: agroforestry, birds, community, role, preference

Received: November 1, 2021 Revised: January 27, 2022 Accepted: February 10, 2022

\section{Introduction}

Agroforestry systems have long been used to meet people's socioeconomic needs, particularly in rural areas around the world (Murthy et al., 2016; Nair, 1993), each with its own characteristics, management techniques, and crop commodities. The Chagga home garden, Matengo Ngoro-Pit system, Ngitilii agroforestry system, and spice agroforestry system are all well-known agroforestry systems that originated in Africa (Kitayli et al., 2013). Some well-known agroforestry systems in Indonesia include Talun in Java (Marten, 1986), Dusun in Mollucas (Matinahoru, 2014), and Pekarangan from the Osing tribe (Hakim et al., 2018). All of these agroforestry systems provide not only economic value, but also ecological services such as habitat for flora and fauna, including birds. Agroforestry may provide birds with natural habitats in which to socialize, nest, and forage (Bohada-Murillo et al., 2020).

Meru Betiri National Park (MBNP) is one of the largest national parks in East Java Province, serving as one of the last remaining natural habitats following the massive deforestation that occurred between 1998 and 1999 (Seidensticker \& Suyono, 1980). Following these events, several initiatives have been launched to revitalize and restore the damage on economy and

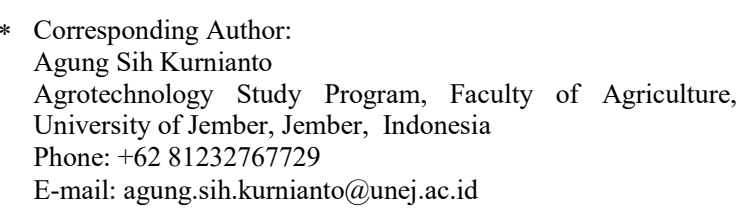

environment, one of which is through agroforestry system. Later, MBNP plants a variety of trees with high economic value, and local residents are permitted to farm in the areas, resulting in the formation of a complex agroforestry system. This buffer zone area is referred to as the rehabilitation area. This rehabilitation area may serve as a suitable habitat for a variety of birds, thereby assisting in the economic development (avitourism) and ecological stability of MBNP (Nawir \& Rumboko, 2007).

The communities and tree-species preferences of birds in a traditional agroforestry system in Meru Betiri National Park were studied in order to gain a better understanding of the birds' diversity and composition in population, which will provide information on key tree species in an agroforestry management system. We anticipate that the study will have a positive effect on the management of agroforestry and threatened buffer zones.

\section{Study site}

The research was conducted in the rehabilitation area of the MBNP in Jember Regency, East Java Province, Indonesia (Figure 1). This study was conducted in two resorts within MBNP. Vegetation analysis and bird observation were conducted on five study sites within the MBNP rehabilitation area: Kandangmotor-1, Kandangmotor-2, Kandangmotor-3 (Resort Andongrejo), Pletes, and Donglo (Resort Wonoasri). Each location was at least one kilometer apart. 


\section{Methods}

We analyze vegetation using the circle method with a radius of $17.1 \mathrm{~m}$. All trees within the radius were identified by species, counted, and their heights were measured. Each location's qualitative parameters data, such as vegetation combinations, the presence of fruit and flowers, and tree use by local residents, were also collected. The research took place during the period of two months: January 2021, representing the rainy season, and August 2021, representing the dry season.

Each location was observed for five days between 06.00 and 08.00 local time (GMT+7). Bird data were collected using the point count method, which entails identifying and counting birds in a circle $\left(360^{\circ}, \mathrm{r}=20 \mathrm{~m}\right)$, with each point count centered on the circle used for the previous vegetation analysis. Bushnell 10-70x70 binoculars were used to observe and identify, and a Canon 1100 D DSLR camera and a Canon III USM $300 \mathrm{~mm}$ Tele Lens were used to document the birds. The species and abundance of birds and vegetation were recorded for further analysis. We classify tree heights into three categories: E (0-1 m), D (1-4 m), and C (4-20 m) (Soerianegara \& Indrawan, 2014), which represent a bird's tree height preference. The activity were classified into three categories: eating/ foraging/ hunting, grouping/ socializing/ communicating, and mating/ parenting/ nesting, recorded on each tree heigh levels. We did not observe during cloudy, rainy, foggy, or windy conditions.

\section{Analysis}

Microsoft Excel was used to tabulate the collected data. The tree community was analyzed using the important value index (IVI), the Shannon-Wiener diversity index $\left(\mathrm{H}^{\prime}\right)$, the Margalef species richness index (Dmg), and the Evennes index (J'). Additionally, the bird ecological roles were presented following Mackinnon et al. (2010). The IVI was defined for tree communities by their density, frequency, and dominance, whereas for bird communities was calculated by their density and encounter frequency. To conduct a more in-depth investigation, Principal Component Analysis (PCA) was used to describe the dominant roles and tree-species preferences using the tree height levels, families, and ecological roles variables.

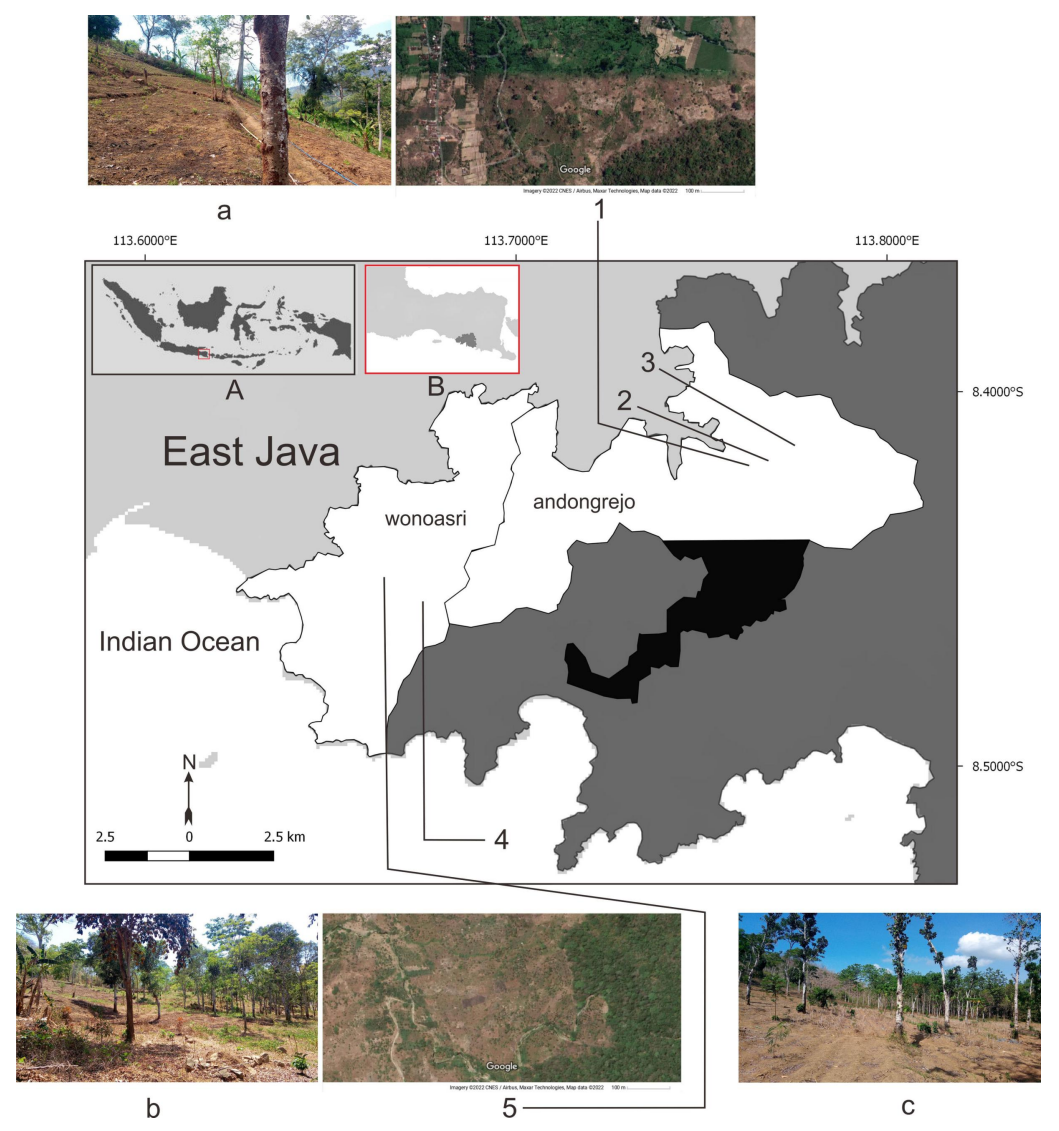

Figure 1. Map of study locations in MBNP agroforestry system. Keys: A. Geographical position of East Java Province, Indonesia; B. Geographical position of MBNP, East Java Province. Colors represent different parts of MBNP: light gray = East Java; dark gray $=$ MBNP area; black $=$ Plantation; white $=$ Andongrejo and Wonoasri resort. Numbers represent study sites: 1 = Kandangmotor-1 included with satellite image; $2=$ Kandangmotor-2; 3 $=$ Kandangmotor-3; $4=$ Pletes; $5=$ Donglo included with satellite image. Small letters represent vegetation: $\mathrm{a}=\mathrm{Kandangmotor}-1 ; \mathrm{b}=$ Donglo; $\mathrm{c}=$ Pletes.

\section{Results}

\section{Tree vegetation community}

A variety of commodity crops, including groundnut and maize, predominated over the tree vegetation. Seven species of trees were found on the study site (Table 1). At Kandangmotor-1, two trees (Parkia speciosa and Mangifera indica) were identified as having a low diversity index $\left(\mathrm{H}^{\prime}=0.64\right)$, a low species richness index $(\mathrm{Dmg}=0.90)$, and an evenly distributed trees $\left(\mathrm{J}^{\prime}=0.92\right)$, 
with $P$. speciosa having the highest important value index $(\mathrm{IVI}=202.12)$.

Three trees (P. speciosa, Nephelium lappaceum, and Hura crepitans) were identified at Kandangmotor-2 as having a moderate diversity index $\left(\mathrm{H}^{\prime}=1.10\right)$, a low species richness index $(\mathrm{Dmg}=1.81)$, and an evenly distributed trees $\left(\mathrm{J}^{\prime}=0.92\right)$, with $H$. crepitans having the highest important value index (IVI = 163.17). Only one tree (H. crepitans) was identified at Kandangmotor-3, limiting analysis of the four indices.

At Pletes, four trees (Artocarpus heterophyllus, $P$. speciosa, M. indica, and Spondias dulcis) were identified with a moderate diversity index $\left(\mathrm{H}^{\prime}=1.00\right)$, a low species richness index $(\mathrm{Dmg}=1.36)$, and a less evenly distributed trees $\left(\mathrm{J}^{\prime}=0.71\right)$, with $A$. heterophyllus having the highest important value index (IVI $=181.09)$.

At Donglo, two trees (Chrysophyllum cainito, and Artocarpus heterophyllus) were identified with a low diversity index $\left(\mathrm{H}^{\prime}=0.65\right)$, a low species richness index $($ Dmg $=0.47)$, and evenly distributed trees $\left(\mathrm{J}^{\prime}=0.94\right)$, with $A$. heterophyllus having the highest important value index $(\mathrm{IVI}=161.91)$

Table 1. Analysis on the tree communities showing the important value index (IVI) of each species and and 3 ecological indices in the study sites in MBNP agroforestry system. Keys = Shannon-Wiener diversity Index $\left(H^{\prime}<1\right.$, low diversity; $1 \leq H^{\prime} \leq 3$, moderate diversity; Wilhm \& Dorris, 1968); Margalef species richness index (Dmg $<3.5$, low species richness; $3.5<$ Dmg $<5$, moderate species richness; Dmg $>5$, high species richness; Magurran, 1988); and Evennes index ( $\mathrm{J}^{\prime}=$ A value close to 1 indicates an increasing degree of evenness).

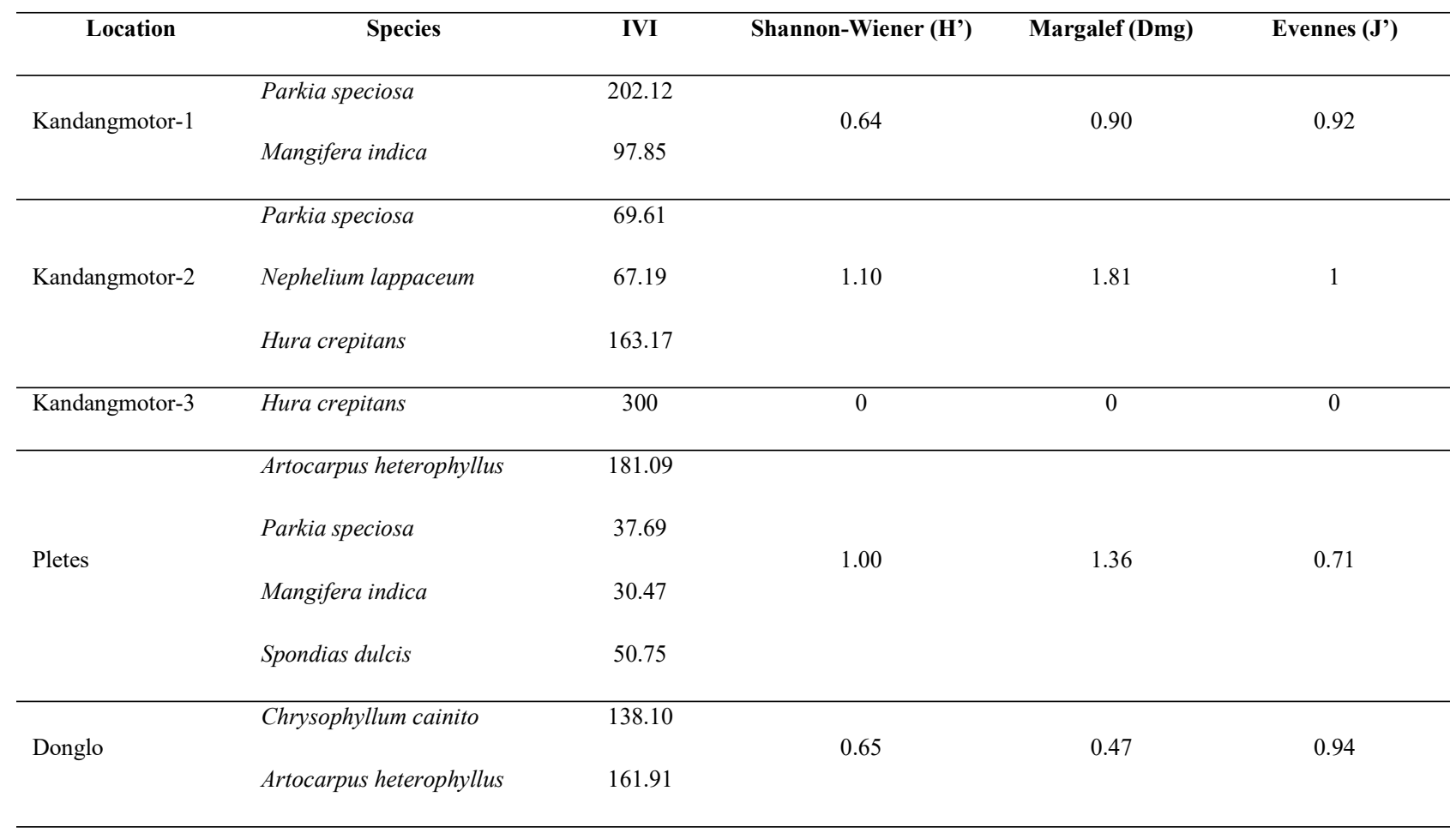

\section{Birds community}

The study sites are home to a variety of birds (Figure 2). Terrestrial insectivores dominated the population at Kandangmotor-1, with the Common Iora having the highest important value index (IVI $=44.32)$ and the Common Tailorbird having the lowest (IVI $=9.37$ ).

At Kandangmotor-2, insectivores hovering near vegetation dominated the population, with the Cave Swiftlet having the highest important value index (IVI = 52.27) and the Crested-serpent Eagle, Javan Kingfisher, and Striated Swallow having the lowest (IVI = 21.59). The Cave Swiftlet's high important value index indicates that the population is abundant, which may also indicate the availability of prey (insects).

The diversity of birds was more pronounced in Kandangmotor-3 than in the previous two sites
(Kandangmotor-1, Kandangmotor-2), with the Rustybreasted Cuckoo having the highest important value index (IVI $=45.00)$ and the Yellow-throated HangingParrot, Olive-backed Sunbird, Plaintive Cuckoo, Striated Grassbird, and Pied Triller having the lowest (both IVI = 22.50). Due to the Rusty-breasted Cuckoo's high important value index, dense vegetation is more common, which the species requires for hiding.

In comparison to Kandangmotor-3, Pletes had a greater diversity of birds, with the Cave Swiflet, as aerial insectivores, dominating and showing the highest important value index (IVI $=68.65)$, and the Olivebacked Sunbird, Crested-serpent Eagle, Plaintive Cuckoo, House 


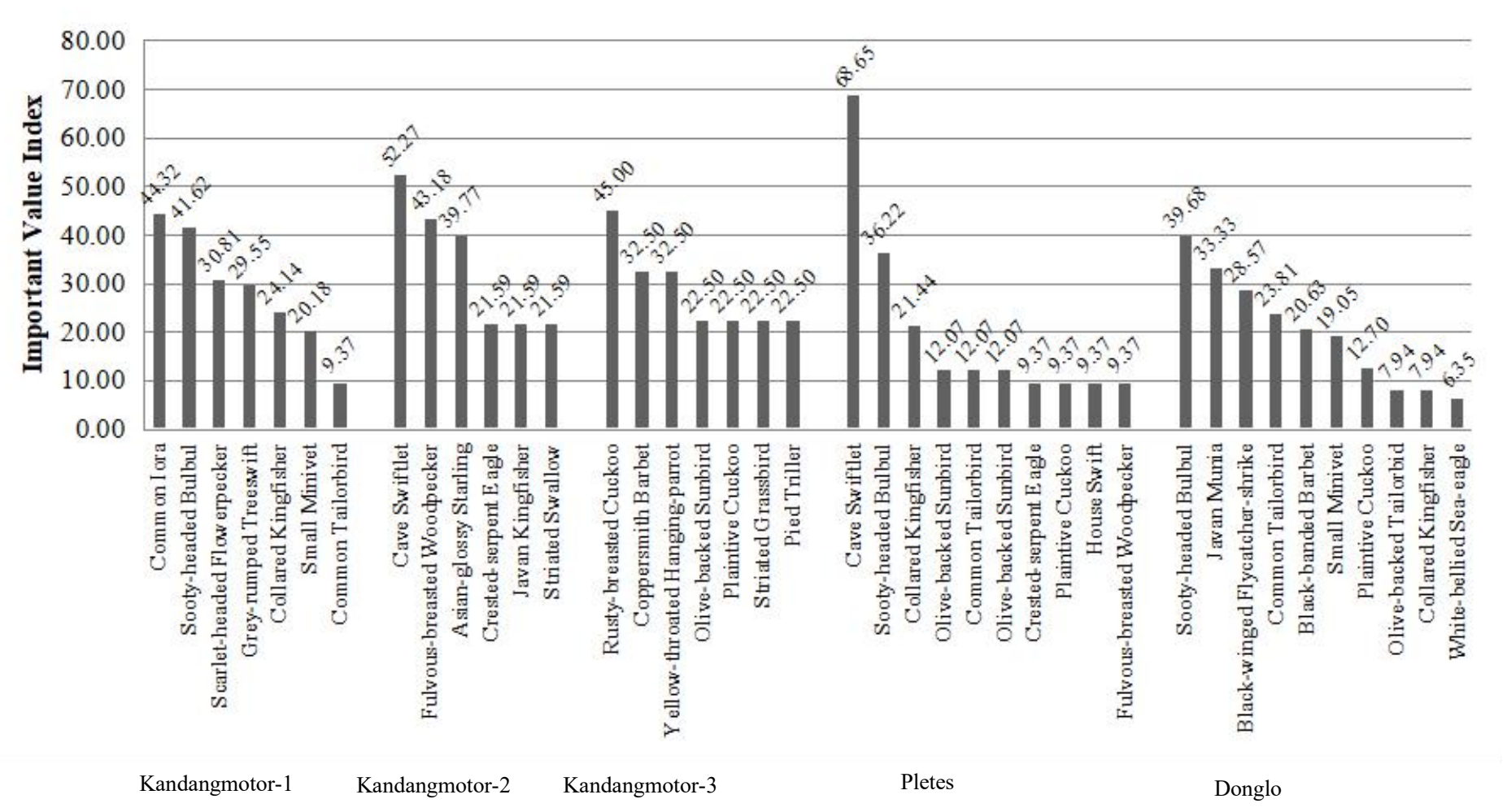

Figure 2. Comparison of important value index of bird species found in the study sites in MBNP agroforestry system.

Swift, and Fulvous breasted Woodpecker having the lowest (both IVI =9.37). Due to the Cave Swiftlet's high important value index, it indicates that prey (insect) was abundant, which could be a result of the traditional agroecosystem management.

In comparison to previous sites, Donglo had the highest bird diversity, with the Sooty-headed Bulbul, as opportunistic omnivorous, having the highest important value index (IVI $=39.68)$ and the White-bellied Seaeagle having the lowest (IVI $=6.35$ ). Because the Sootyheaded Bulbul has a high important value index, it indicates that their food source ( $C$. cainito's fruit) was plentiful.

\section{Tree-species preference of birds}

Tree-sepcies preference were provided by excluding bird that do not use trees directly (only hover/ pass through) (Figure 3). Kandangmotor-1 contains two tree species ( $P$. speciosa and $M$. indica) that are visited by seven bird species. The $P$. speciosa was visited by Greyrumped Treeswift ( 6 individuals), Sooty-headed Bulbul (6 individuals), Common Iora (6 individuals), Scarletheaded Flowerpecker (4 individuals), and Collared Kingfisher ( 3 individuals). The $M$. indica was visited by Small Minivet (5 individuals), Sooty-headed Bulbul (2 individuals), Common Iora (3 individuals), Common Tailorbird (1 individual), and Collared Kingfisher (1 individual).

Kandangmotor-2 contains two tree species ( $P$. speciosa and $H$. crepitans) that are visited by four bird species. The P. speciosa was visited by Asian-glossy Starling (2 individuals) and Fulvous-breasted Woodpecker ( 1 individual). The $H$. crepitans was visited by Asian-glossy Starling (1 individual), Striated Swallow
(1 individual), Javan Kingfisher (1 individual), and Fulvous-breasted Woodpecker (1 individual).

Kandangmotor-3 contains one tree species $(H$. crepitans) that are visited by seven bird species. The $P$. speciosa was visited by Yellow-throated Hanging-parrot ( 2 individuals), Plaintive Cuckoo (1 individual), Rustybreasted Cuckoo (2 individuals), Coppersmith Barbet (2 individuals), Pied Triller (1 individual), Striated Grassbird (1 individual), and Olive-backed Sunbird (1 individual).

Pletes contains three tree species (A. heterophyllus, $P$. speciosa, and $H$. crepitans) that are visited by seven bird species. The $A$. heterophyllus was visited by Sootyheaded Bulbul (6 individuals), Common Tailorbird (2 individuals), Collared Kingfisher (1 individual), Olivebacked Tailorbird (1 individual), and Olive-backed Sunbird ( 2 individuals). The $P$. speciosa was visited by Olive-backed Tailorbird (1 individual), Collared Kingfisher (2 individuals), and Fulvous-breasted Woodpecker ( 1 individual). The $M$. indica was visited by Plaintive Cuckoo only (1 individual).

Donglo contains two tree species ( $C$. cainito, and $A$. heterophyllus) that are visited by nine bird species. The C. cainito was visited by Plaintive Cuckoo (2 individuals), Black-banded Barbet (1 individual), Small Minivet (2 individuals), Black-winged Flycatcher-shrike (3 individuals), Olive-backed Tailorbird (1 individual), and Collared Kingfisher (2 individuals). The $A$. heterophyllus was visited by Black-banded Barbet (3 individuals), Small Minivet (6 individuals), Blackwinged Flycatcher-shrike (5 individuals), Sooty-headed Bulbul (16 individuals), Common Tailorbird (6 individuals), Olive-backed Tailorbird (1 individual), and Javan Munia (12 individuals). 


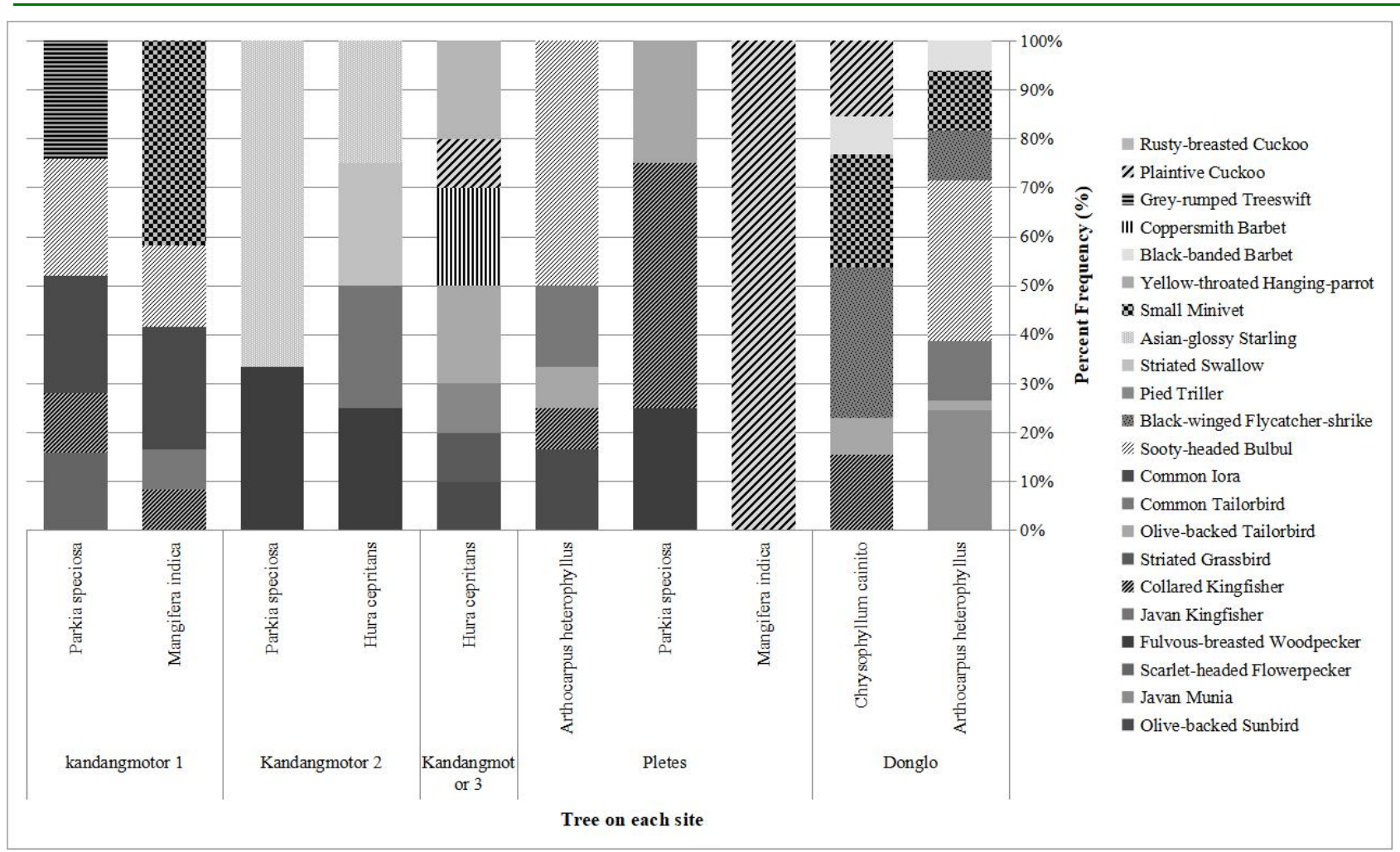

Figure 3. Tree-species preference of birds showed by the percent frequency of birds doing activity on several tree species at study locations in MBNP agroforestry system

\section{Ecological roles and activity's preference of birds based on tree height levels}

Birds' ecological roles and activity preferences are described for all individuals recorded at each site across all tree height levels (Figure 4; Table 2). According to their ecological roles, the majority of bird families (11 out of 16) were composed of insectivores, which were found at all tree height levels. Picidae were observed visiting level-D ( 2 individuals) and level-C (1 individual); Locustellidae were observed visiting only level-D (1 individual); Cisticolidae were observed at all three levels: level-E (7 individuals), level-D (5 individuals), and level-C (3 individuals); The activities of Aegithinidae were recorded at two levels: level-D (7 individuals) and level-C (2 individuals); Pycnonotidae was the most prevalent insectivore family observed at all levels: levelE ( 2 individuals), level-D (9 individuals), and level-C (20 individuals); Campephagidae was the second most prevalent insectivores family observed at level-D (2 individuals), and level-C (22 individuals); Hirundinidae was observed visiting level-C (1 individual); Sturnidae was observed visiting level-C (3 individuals); Psittaculidae was observed visiting level-C (2 individuals); Hemiprocnidae was observed visiting levelC (6 individuals); and Cuculidae was observed visiting level-C only (6 individuals).

Estrildidae was one family that was recorded with an ecological role of pest at all three levels: level-E (3 individuals), level-D (4 individuals), and level-E (5 individuals). Two families were identified as pollinators: Nectariniidae and Dicaeidae. Nectariniidae were only recorded at level-D (3 individuals), whereas Dicaeidae were recorded at both levels-D (1 individual) and level-E (3 individuals).

Alcedinidae was one family with a predatory role that spread across two levels: level-D (8 individuals) and level-C ( 2 individuals).Across tree height levels, bird activities were classified into three broad categories: eating/ foraging/ hunting (Et), grouping/ socializing/ communicating (Gr), and mating/ parenting/ building a nest (Ma) (Table 2). Based on bird's activity in level-E, Cisticolidae (7 individuals) and Pycnonotidae (2 individuals) were observed foraging and searching for food. Estrildidae (3 individuals) were observed to cluster together.

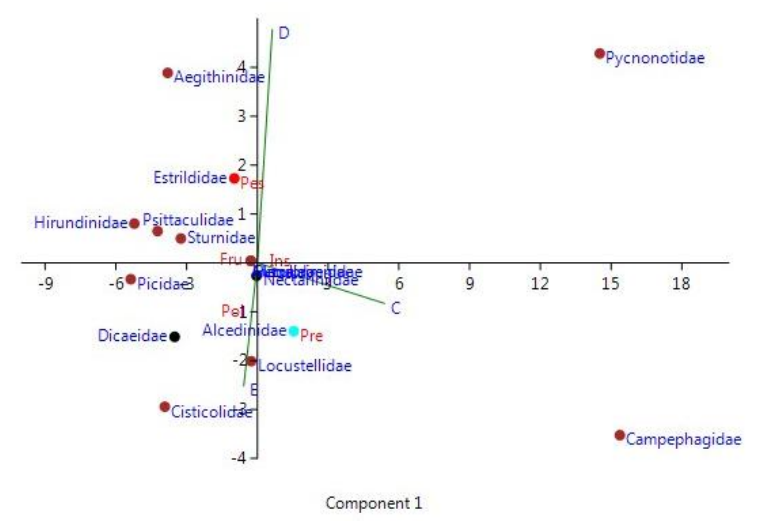

Figure 4. Principal Component ordination charts with variables representing family, ecological roles, and tree height levels in MBNP agroforestry system. The red area indicated the predominance of families classified as insectivores. Keys: level-E (0-1 m), level-D (1-4 $\mathrm{m})$, and level-C (4-20 m); Activity: Ins (Insectivore), Pes (Pest), Pol (Pollinator), Pre (Predator), Fru (Frugivore). 
At level-D, eight families involved in eating/ foraging/ hunting activities: Picidae (2 individuals), Cisticolidae (3 individuals Aegithinidae (2 individuals), Pycnonotidae (1 individual), Estrildidae (4 individuals), Nectariniidae (1 individual), Dicaeidae (1 individual), and Alcedinidae (4 individuals). Six families demonstrated grouping/ socializing/ communicating activities: Locustellidae (1 individual), Aegithinidae (3 individuals), Pycnonotidae (6 individuals), Campephagidae (2 individuals), Nectariniidae (2 individuals), and Alcedinidae (4 individuals). Three families indicated mating/ parenting/ building nest activities: Cisticolidae (2 individuals), Aegithinidae (2 individuals), and Pycnonotidae (2 individuals).

According to level-C, the activities of eating/ foraging/ hunting were observed in 7 families:
Megalaimidae (2 individuals), Picidae (1 individual), Aegithinidae (2 individuals), Pycnonotidae (5 individuals), Campephagidae (10 individuals), Sturnidae (1 individual), and Dicaeidae (3 individuals). Ten families demonstrated the grouping/ socializing/ communicating activities: Megalaimidae, (4 individuals), Cisticolidae (3 individuals), Pycnonotidae (11 individuals), Campephagidae (12 individuals), Hirundinidae (1 individual), Sturnidae (2 individuals), Psittaculidae (2 individuals), Hemiprocnidae (6 individuals), Cuculidae (4 individuals), and Estrildidae (5 individuals). The mating/ parenting/ building nest activities were indicated by 2 families: Cuculidade (2 individuals) and Alcedinidae ( 2 individuals).

Table 2. Number of individuals, ecological role, tree height levels and activity of birds at study in MBNP agroforestry system. Keys: level-E (0-1 meters), level-D (1-4 meters), and level-C (4-20 meters); Ecological role: Pes (Pest), Pol (Pollinator), Pre (Predator); Activity: Et (eating/ foraging/ hunting), Gr (Grouping/ socializing/ communicating), Ma (Mating/ parenting/ building a nest)

\begin{tabular}{|c|c|c|c|c|c|c|c|c|c|c|}
\hline \multirow[t]{2}{*}{ Family } & \multirow{2}{*}{$\begin{array}{c}\text { Ecological } \\
\text { Role }\end{array}$} & \multicolumn{3}{|c|}{$\mathbf{E}$} & \multicolumn{3}{|c|}{ D } & \multicolumn{3}{|c|}{$\mathbf{C}$} \\
\hline & & $\mathbf{E t}$ & $\mathbf{G r}$ & Ma & $\mathbf{E t}$ & Gr & Ma & Et & Gr & Ma \\
\hline Megalaimidae & Fru & & & & & & & 2 & 4 & \\
\hline Picidae & Ins & & & & 2 & & & 1 & & \\
\hline Locustellidae & Ins & & & & & 1 & & & & \\
\hline Cisticolidae & Ins & 7 & & & 3 & & 2 & & 3 & \\
\hline Aegithinidae & Ins & & & & 2 & 3 & 2 & 2 & & \\
\hline Pycnonotidae & Ins & 2 & & & 1 & 6 & 2 & 5 & 11 & 4 \\
\hline Campephagidae & Ins & & & & & 2 & & 10 & 12 & \\
\hline Hirundinidae & Ins & & & & & & & & 1 & \\
\hline Sturnidae & Ins & & & & & & & 1 & 2 & \\
\hline Psittaculidae & Ins & & & & & & & & 2 & \\
\hline Hemiprocnidae & Ins & & & & & & & & 6 & \\
\hline Cuculidae & Ins & & & & & & & & 4 & 2 \\
\hline Estrildidae & Pes & & 3 & & 4 & & & & 5 & \\
\hline Nectariniidae & Pol & & & & 1 & 2 & & & & \\
\hline Dicaeidae & Pol & & & & 1 & & & 3 & & \\
\hline Alcedinidae & Pre & & & & 4 & 4 & & & & 2 \\
\hline
\end{tabular}

\section{Discussion}

Shade plants are critical in maintaining the ecological and microclimatic conditions of the agroforestry ecosystem (Nair, 1993). Its survival is inextricably linked to the role of fauna in assisting the succession and attracting additional activity. For example, frugivores aid in long-distance seed dispersal, and numerous nectarivores act as pollinators, accelerating plant reproduction. However, the rehabilitation/ study areas within MBNP agroforestry system are sparsely vegetated. The A. heterophyllus, surprisingly, is the tree that attracts the most birds in a variety of roles. For instance, insectivores birds prey on insects attracted to fruit and flowers in rehabilitation/ study areas. Additionally, birds are attracted to $H$. crepitans due to its large canopy. According to the current study, these two tree species were preferred over others that attract a diverse range of bird species.

MBNP's efforts to plant these shade trees in order to restore the damaged forests during the early reformation era (Nawir \& Rumboko, 2007) had a positive effect on bird diversity. Numerous fruit trees with a high economic value have demonstrated a positive effect on encouraging people to care for them while also reaping ecological and economic benefits.

At level-C, activity preferences indicate a high level of activity. This evidence demonstrates the characteristics of agroforestry, which provides shelter, socialization, and nesting sites for birds in the canopy while also feeding the vegetation below. In three activities observed, grouping/ socialization/ communication was found to be more prevalent than other activities, the majority of which were attributed to the grouped insectivores' birds (Campephagidae and Pycnonotidae). Both groups engage in solitary or mixed insect hunting (Mackinnon et al., 2010; Kurnianto et al., 2020).

Insectivores' birds are a highly effective group for pest population control. Each year, they can consume up to 400-500 metric tons of insects (Nyffeler et al., 2018). However, the extinction of these bird species has a significant impact on agricultural lands and human 
settlements (Canaday, 1996). Additionally, other groups favored level-C: Megalaimidae is a frugivore family that is more active in the canopy, blends into the leaf color, and has a monotone voice (MacKinnon et al., 2010). Moreover, phylogenetic analysis reveals a relationship between song length and frequency and taxa relationships. Vocal signals also play a critical role in reproductive isolation and speciation in these species (Gomes et al., 2008; GonzalezVoyer et al., 2013).

Frugivores have a significant impact on forest ecosystem restoration and secondary areas (Purificaço et al., 2014). Additionally, the frugivore bird is capable of dispersing weed seeds throughout tea plantations. The seeds distributed have a potency that is 1.43-5.71 percent greater than seeds that do not pass through the digestive tract (Partasasmita, 2017). Mutualism is an asymmetrical interaction between fruiting plants and frugivorous birds. However, it is well established that the fruit's energy content is related to the diversity of visiting birds (Sebastián-González, 2017).

Mating is a critical life stage for birds. This behavior indicates that birds are residents of the habitat and play a critical ecological role in it. At level-D and level-C, five bird families have been observed mating: Cisticolidae, Aegithinidae, Pycnonotidae, Cuculidae, and Alcedinidae. Except for Alcedinidae, they are all insectivores.

As a result of agricultural activity, insect populations are also more abundant in agroforestry areas. This is addressed ecologically through the presence of birds, the majority of which serve as insectivores. These birds' presence is critical for insect pest control (Bael et al., 2008). Eleven of the sixteen families have been identified as insectivores, with the remainder acting as pests, predators, frugivores, and pollinators. Birds have long been recognized as requiring agricultural landscapes as a habitat (Goijman et al., 2015). Their presence is critical for controlling pests, particularly those that are resistant to conventional control methods. Conflicts resulting from the presence of birds in agroecosystems are frequently unresolvable through policy. However, certain actions, such as planting shrubs and trees, have a mitigating effect on agriculture and bird populations (Pejchar et al., 2018).

Pest Estrildidae have preference for level-E and level-D. These levels are utilized for social purposes as well as foraging on the commodity land below. Estrildidae has been identified as a pest in rice farming (DeGrazio, 1978). During the generative period, Estrildidae attacks occur. The color of the rice spikelet changes, which is thought to attract birds (Arisoesilaningsih, 2013). However, attacks are typically carried out by mixed groups of species, with one or two species having the greatest population. In Malaysia, researchers discovered that bird pests attacks were both local and temporal, resulting in yield losses of up to 0.2 percent per season. Given the scarcity of recent references to estrildid pests and other birds, this damage record may differ from that of other areas.

According to each study site, it was discovered that Common Iora were abundant as terrestrial insectivores in Kandangmotor-1 (IVI $=44.31)$, Cave Swiftlets were abundant as aerial insectivores in Kandangmotor-2 (IVI
$=$ 52.26) and Pletes (IVI = 68.65), Rusty-breasted Cuckoos were extremely common in Kandangmotor-3, and Sooty-headed Bulbul were a common insectivores in study sites.

It can be concluded that the primary predators of insects in the traditional MBNP agroforestry system are insectivores birds. The A. heterophyllus was the most visited tree species, which may have important ecological and economic benefits. Ultimately, one can conclude that the majority of bird activity takes place at level-C (canopy).

\section{Acknowledgement}

We would like to express our gratitude to Meru Betiri National Park for granting us permission to conduct research. Additionally, we appreciate the officers in Andongrejo and Wonoasri for providing impeccable field guidance. Additionally, forest farming communities have provided valuable information about agricultural and animal conditions.

\section{References}

Arisoesilaningsih, E. (2013). Pertumbuhan padi hitam dan serangan beberapa herbivor di sawah padi organik kecamatan kepanjen. Biotropika: Journal of Tropical Biology, 1(5), 221-225.

Bael, S. A. Van, Philpott, S. M., Greenberg, R., Bichier, P., Barber, N. A., Mooney, K. A., \& Gruner, D. S. (2008). Birds as predators in tropical agroforestry systems. Ecology, 89(4), 928-934.

Bohada-Murillo, M., Castaño-Villa, G. J., \& Fontúrbel, F. E. (2020). The effects of forestry and agroforestry plantations on bird diversity: A global synthesis. Land Degradation \& Development, 31(5), 646-654.

Canaday, C. (1996). Loss of insectivorous birds along a gradient of human impact in Amazonia. Biological Conservation, 77(1), 63-77.

De Foresta, H., Kusworo, A., Michon, G., \& Djatmiko, W. A. (2000) Ketika kebun berupa hutan: Agroforest khas Indonesia sebuah sumbangan masyarakat. ICRAF, Bogor, 249.

DeGrazio, J. W. (1978). World bird damage problems. In Proceedings of the Vertebrate Pest Conference (Vol. 8).

Goijman, A. P., Conroy, M. J., Bernardos, J. N., \& Zaccagnini, M. E. (2015). Multi-season regional analysis of multi-species occupancy: implications for bird conservation in agricultural lands in east-central Argentina. PloS One, 10(6), e0130874.

Gomes, L. G. L., Oostra, V., Nijman, V., Cleef, A. M., \& Kappelle, M. (2008). Tolerance of frugivorous birds to habitat disturbance in a tropical cloud forest. Biological Conservation, 141(3), 860871.

Gonzalez-Voyer, A., den Tex, R., Castelló, A., \& Leonard, J. A. (2013) Evolution of acoustic and visual signals in Asian barbets. Journal of Evolutionary Biology, 26(3), 647-659.

Hakim, L., Pamungkas, N. R., Wicaksono, K. P., \& Soemarno, S. (2018). The Conservation of Osingnese Traditional Home Garden Agroforestry in Banyuwangi, East Java, Indonesia. AGRIVITA, Journal of Agricultural Science, 40(3), 506-514.

MacKinnon, J., Phillipps, K., \& Van Balen, B. (2010). Burung-burung di Sumatera, Jawa, Bali dan Kalimantan. Burung Indonesia. Bogor.

Marten, G. G. (1986). Traditional agriculture in Southeast Asia: a human ecology perspective.

Matinahoru, J. M. (2014). A Review on Dusun as an indigenous agroforestry system practiced in small islands. 南太平洋海域 調查研究報告= Occasional Papers, (54), 53-60.

Murthy, I. K., Dutta, S., \& Vinisha, V. (2016). Impact of agroforestry sytems on ecological and socioeconomic systems: a review. Glob J Sci Front Res: H Environ Earth Sci, 16(5), 15-27.

Nair, P. K. R. (1993). An Introduction to Agroforestry by Kluwer Academic Publishers. The Netherlands. 
Nawir, A. A., \& Rumboko, L. (2007). Forest rehabilitation in Indonesia: where to after more than three decades? Center for International Forestry Research (CIFOR).

Nyffeler, M., Şekercioğlu, Ç. H., \& Whelan, C. J. (2018). Insectivorous birds consume an estimated 400-500 million tons of prey annually. The Science of Nature, 105(7), 1-13.

Partasamsita, R. (2017). The role of frugivorous birds in the dispersal of shrubs in submontane zone of tropical forest, West Java, Indonesia. JURNAL NASIONAL, 7(2), 144-148.

Pejchar, L., Clough, Y., Ekroos, J., Nicholas, K. A., Olsson, O. L. A., Ram, D., Smith, H. G. (2018). Net effects of birds in agroecosystems. BioScience, 68(11), 896-904.
Purificação, K. N., Pascotto, M. C., Pedroni, F., Pereira, J. M. N., \& Lima, N. A. (2014). Interactions between frugivorous birds and plants in savanna and forest formations of the Cerrado. Biota Neotropica, 14(4).

Sebastián-González, E. (2017). Drivers of species' role in avian seed-dispersal mutualistic networks. Journal of Animal Ecology, 86(4), 878-887.

Seidensticker, J., \& Suyono, I. (1980). The Javan tiger and the MeruBetiri Reserve: A plan for management.

Soerianegara, I., \& Indrawan, I. (2014). Ekologi hutan Indonesia. Bogor : Laboratorium Ekologi hutan, Fakultas Kehutanan, Institut Pertanian Bogor 